\title{
Computed tomography-guided fine-needle aspiration biopsy
}

\author{
Departments of Anatomic Pathology and Radiology, A.C. Camargo Hospital \\ Antonio Prudente Foundation - São Paulo, Brazil
}

\begin{abstract}
The therapeutic and prognostic evaluation of malignant neoplasias depends largely upon a precise morphologic diagnosis. Several papers have focused on the importance of fine-needle aspiration under computed tomography guidance in the diagnosis of unresectable neoplasms and in the investigation of metastases. The objective of this study is to evaluate the diagnostic accuracy, the sensitivity, and the negative predictive value obtained with the technique. Fine-needle aspiration cytology (FNAC) was performed on 207 patients, with a total of 210 cases, from 1991 to 1994 , under computed tomography (CT) guidance. There were 128 (61.8 percent) males and 79 (38.2 percent) females with a mean age of 41 years (range 1 to 91 years). Lung and liver were the most frequent anatomic sites. The analysis of this material disclosed 41 cases with cytological diagnosis of negative for malignancy (19.52 percent), and in 131 (62.38 percent), the diagnosis was positive. It was possible to define the cytologic lineage in 54 percent of the cases. The diagnosis in 14 (6.67 percent) cases was suspicious for malignancy, and in 24 ( 11.43 percent) cases the material was insufficient for the cytologic diagnosis. Of the 210 cases, 106 showed histological diagnosis and/ or clinical follow-up. Forty-seven ( 44.3 percent) had histological diagnosis before the FNAC and 50 cases ( 56.7 percent) histological diagnosis after the procedure. The comparison between cytological and histological diagnosis showed a sensibility of 80.4 percent, specificity of 100 percent, positive predictive value of 100 percent and negative of 16.7 percent. The efficiency of the test was 81.1 percent. This study showed that FNAC, under computed tomography guidance, is a sensitive and specific technique for the diagnosis of deep-seated lesions.
\end{abstract}

UNITERMS: Biopsy-needle, cytological techniques, cytodiagnosis, fine-needle aspiration.

\section{INTRODUCTION}

$\mathrm{F}$ line-needle aspiration biopsy (FNAB) is an outpatient method used for the evaluation of palpable masses. The assessment of deep-seated, non-palpable lesions requires imaging methods, computed tomography (CT) in particular. FNAB application is important for the diagnosis of advanced and unresectable neoplasias as available results have confirmed the effectiveness and safety of this technique, ${ }^{3}$ which is indicated for the investigation of benign or malignant, primary or metastatic neoplasias. A precise morphologic diagnosis is essential

\section{Address for correspondence:}

Gilda da Cunha Santos

Rua Itapeva, 500 Conj. 7A - Bela Vista

São Paulo/SP - Brasil - CEP 01332-000 for the planning of treatment and the prognosis of malignant neoplasias. Several reports have emphasized the high specificity and sensitivity of CT-guided aspirative cytology..$^{2.9 .10}$

The present report presents the results obtained with CT-guided FNAB and compares them to those obtained by histology of biopsy material and surgical specimens, and in terms of the clinical follow-up of the patients in order to establish the diagnostic accuracy of the method.

\section{MATERIAL AND METHODS}

We studied 210 CT-guided aspirative biopsies carried out at A.C. Camargo Hospital from June 1991 to June 
1994. All cases were submitted to the classical FNAB technique ${ }^{6}$ using a Franzen type cytoaspiration gun coupled to a $10 \mathrm{ml}$ disposable syringe with a disposable needle commonly used for spinal anesthesia, $0.7 \mathrm{~mm}$ in outer diameter $(22 \mathrm{G})$. The procedures were carried out under the guidance of a tomography apparatus (CT MAX, General Electric).

The smears were fixed in 95 percent alcohol and stained by the Papanicolaou and H\&E techniques. Airdried slides were then submitted to Giemsa staining. In some cases, part of the material obtained was fixed in 10 percent formalin and embedded in paraffin for the preparation of a cell block, and the slides were stained by the H\&E technique.

The positive and negative cytologic diagnoses were considered to be true or false in relation to the histopathologic diagnoses and clinical follow-up of the patients. On the basis of these data, statistical indices of clinical-laboratory importance were calculated, such as specificity, sensitivity, positive and negative predictive value, and efficiency. ${ }^{1.8}$ Cases with a suspicious or inconclusive cytologic diagnosis, and cases with no histopathologic examination, were excluded from the statistical analysis.

The patients were divided into cases with a histopathologic diagnosis obtained before the aspirative biopsy, and cases with an anatomopathologic report and/ or clinical follow-up after the cytologic examination.

\begin{tabular}{lrr}
\hline \multicolumn{4}{c}{$\begin{array}{c}\text { Table 1 } \\
\text { Patient distribution by age range in } 207 \text { patients } \\
\text { submitted to FNA. }\end{array}$} \\
\hline Age range & \multicolumn{2}{c}{ Frequency } \\
& N & $(\%)$ \\
\hline $0-10$ & 7 & $(3.4)$ \\
$11-20$ & 5 & $(2.4)$ \\
$21-30$ & 5 & $(2.4)$ \\
$31-40$ & 15 & $(7.3)$ \\
$41-50$ & 23 & $(11.1)$ \\
$51-60$ & 42 & $(20.3)$ \\
$61-70$ & 67 & $(32.4)$ \\
$71-80$ & 34 & $(16.4)$ \\
$>80$ & 9 & $(4.3)$ \\
\hline Total: & 207 & $100 \%$ \\
\hline
\end{tabular}

\section{RESULTS}

The 210 aspirative biopsies were performed on 207 patients, 128 males ( 61.8 percent) and 79 females (38.2 percent). Patient age ranged from 1 to 91 years (mean 41 years), with a larger number of cases situated in the seventh decade of life (Table 1). The procedures were performed from July 1991 to June 1994 . Table 2 shows their distribution by year. The biopsies were obtained from different locations, with the lung and liver being the most frequent (Figs. 1,2 and 3 ). Table 2 shows their distribution by location.

\begin{tabular}{|c|c|c|}
\hline \multicolumn{3}{|c|}{$\begin{array}{c}\text { Table } 2 \\
\text { Distribution of FNAB by anatomic sites }\end{array}$} \\
\hline \multirow[t]{2}{*}{ Location } & \multicolumn{2}{|c|}{ Frequency } \\
\hline & $\mathrm{N}$ & (\%) \\
\hline $\begin{array}{l}\text { Lung } \\
\text { Liver }\end{array}$ & $\begin{array}{r}110 \\
23\end{array}$ & $\begin{array}{l}(52.4) \\
(11.0)\end{array}$ \\
\hline $\begin{array}{l}\text { Mediastinum } \\
\text { Adrenal gland }\end{array}$ & & $\begin{array}{l}16 \\
11\end{array}$ \\
\hline Chest wall & 09 & \\
\hline $\begin{array}{l}\text { Pelvic cavity } \\
\text { Orbit }\end{array}$ & 07 & 07 \\
\hline Abdominal cavity & 06 & \\
\hline $\begin{array}{l}\text { Kidney } \\
\text { Spine }\end{array}$ & & $\begin{array}{l}06 \\
04\end{array}$ \\
\hline Pancreas & & 03 \\
\hline Others & & 08 \\
\hline Total & 210 & (100) \\
\hline
\end{tabular}

The diagnosis for the presence of neoplastic cells was negative in 41 cases ( 19.52 percent) and positive in 131 ( 62.38 percent). The diagnosis of the cell lineage was possible in 54 percent of the latter cases. A suspicious diagnosis (atypical cells) was made in 14 cases (6.67 percent), and in 24 cases ( 11.43 percent) the material was considered insufficient. Of the 207 patients studied, 106 had an anatomopathologic examination and/or clinical follow-up. A diagnosis preceding the aspirative biopsy was available in 47 cases ( 44.3 percent), and a histopathologic examination following the biopsy was obtained in 50 cases (56.7 percent).

Comparison of the cytologic and histopathologic diagnoses revealed 82 cases of true-positive results (77.3 percent), 4 cases with true-negative results ( 3.8 percent), no false-positive case, and 20 cases with false-negative results (18.9 percent) (Table 3 ). The test showed 80.4 


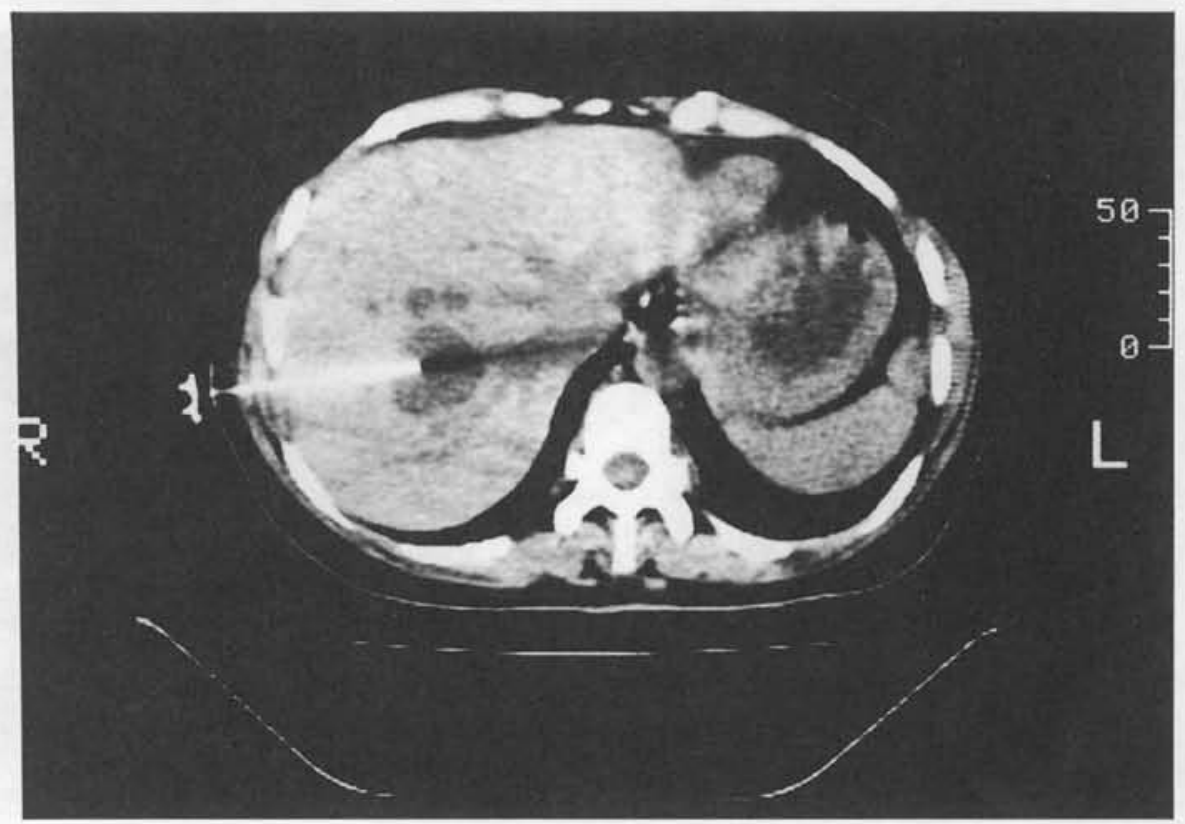

Figure 1 - Axial tomography section of the liver showing the position of the needle in a nodular lesion.

percent sensitivity, 100 percent specificity, 100 percent positive predictive value, 16.7 percent negative predictive value, and 81.1 percent efficiency (Table 4).

\section{DISCUSSION}

The present study showed that CTguided FNAB is a sensitive and highly specific technique for the diagnosis of deepseated lesions, with results similar to those obtained in previous investigations. ${ }^{2.9}$ The method has proved to be reproducible at several medical centers and is being applied for the diagnosis of neoplasias, especially unresectable lesions or lesions of difficult surgical access, and for the confirmation of metastases. Analysis of the results revealed that approximately 44 percent of patients with an anatomopathologic examination (47 cases) presented a previous diagnosis, with FNAB being used to evaluate metastases.

Because of the inherent characteristics of FNAB, which uses small-gauge needles $(22 \mathrm{G})$, the method is safe, without the risks of more invasive methods. Furthermore, it permits the use of appropriate treatment by offering a precise typing of the neoplasias in a significant number of cases, with the consequent avoidance of risky major
Table 3

Positive and negative cytologic cases considered true or false after correlation with the anatomoclinical diagnosis

\begin{tabular}{lrrr}
\hline Diagnosis & $\begin{array}{r}\text { Later AC } \\
(\mathrm{N})\end{array}$ & $\begin{array}{r}\text { Previous AC } \\
(\mathrm{N})\end{array}$ & Total \\
\hline True positive & 44 & 38 & $82(77.3 \%)$ \\
True negative & 4 & 0 & $4(3.8 \%)$ \\
False positive & 0 & 0 & 0 \\
False negative & 11 & 9 & $20(18.9 \%)$ \\
\hline Total & 59 & 47 & 106 \\
\hline
\end{tabular}

$\mathrm{AC}=$ Anatomopathologic and/or clinical diagnosis .

surgery. ${ }^{2}$ The method permits a precise morphologic diagnosis, reducing the need for diagnostic thoracotomies in 31-35 percent of cases. ${ }^{7.12}$ FNAB offers several advantages over other diagnostic methods, especially in thoracic lesions: it is rapid, does not require general anesthesia or prolonged hospitalization, and is less costly and more tolerable to patients compared to surgery or mediastinoscopy. ${ }^{15}$

In cases of hepatic lesions, the major advantage of FNAB compared to standard-needle biopsy is its higher success rate in detecting malignant neoplasias. The discrepancy between these two methods with respect to tumor detection is related to the relatively atraumatic nature of FNAB, which permits multiple punctures of the lesion, whereas the number of procedures (or attempts) with a 


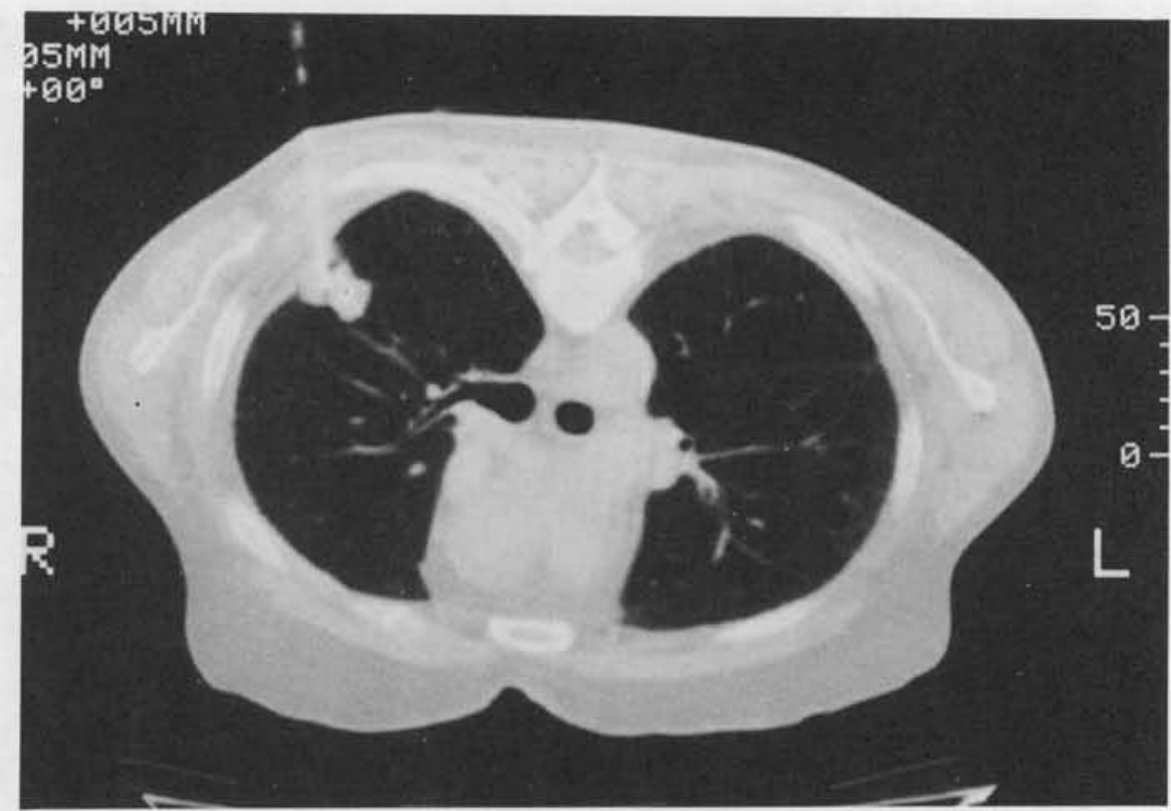

Figure 2 - Axial tomography section of the chest with a patient in ventral decubitus. Note the distal end of the needle positioned inside a nodular lesion of the lung.

thick needle is limited by the potential occurrence of severe complications. ${ }^{13}$

The frequency of insufficient material (11.43 percent) was similar to that obtained in other studies. ${ }^{2.9}$ In the case of superficial palpable lesions of easier access, the index of unsatisfactory material, which includes insufficient samples, samples that are not representative of the organ and samples represented by blood elements, is variable. The index for mammary lesions ranges from 3 to 36 percent, and the index for thyroid lesions ranges from 8 to 18 percent (4). The proportion of unsatisfactory aspirates decreases with increasing experience with the procedure on the part of the operator. ${ }^{4}$

It has been suggested that honest communication with clinicians about the quality of the cytologic contribution to the patient management and its limitations could reduce the number of false-positive results." Although some lesions are difficult to interpret both in terms of discriminating malignancy and in terms of histogenetic characterization, no false-positive cases occurred in the present study, explaining the high specificity detected.

The percentage of false-negative results was 18.86 percent. Thus, a negative result does not exclude the presence of a malignant neoplasia and the examination should be repeated. In the present series, no new aspirative biopsies were taken. However, it is known that positivity
Table 4

Indices of the diagnostic performance of fine-needle aspirative cytology

\begin{tabular}{lrrr}
\hline Indices & $\begin{array}{r}\text { Later AC } \\
(\%)\end{array}$ & $\begin{array}{r}\text { Previous AC } \\
(\%)\end{array}$ & Total \\
\hline Sensitivity & 80.0 & 80.8 & 80.4 \\
Specificity & 100.0 & $100.0^{\star}$ & 100.0 \\
(+) Predictive value & 100.0 & $100.0^{\star}$ & 100.0 \\
(-) Predictive value & 26.6 & $\star \star$ & 16.7 \\
Efficiency & 81.3 & 80.8 & 81.1 \\
\hline
\end{tabular}

${ }^{*}$ Considered to be $100 \%$ because there were no false-positive results

"* Not calculated.

increases with repeated procedures. ${ }^{14}$ Among the factors responsible for false-negative results are peritumoral infarction, inflammation and fibrosis. ${ }^{2}$ A low index of false-negative diagnoses has been considered to be the result of intense cooperation and communication between pathologist and radiologist, with a negative result being considered definitive for those cases in which the morphologic and radiologic aspects indicate a benign process. $^{2}$

Sensitivity and specificity were within the range reported for aspirative biopsies of thoracic lesions, i.e., 71 to 100 percent and 95 to 100 percent, respectively. ${ }^{2.5 .7 .10 .16}$ The results revealed that there was no difference in sensitivity, specificity or efficiency between 


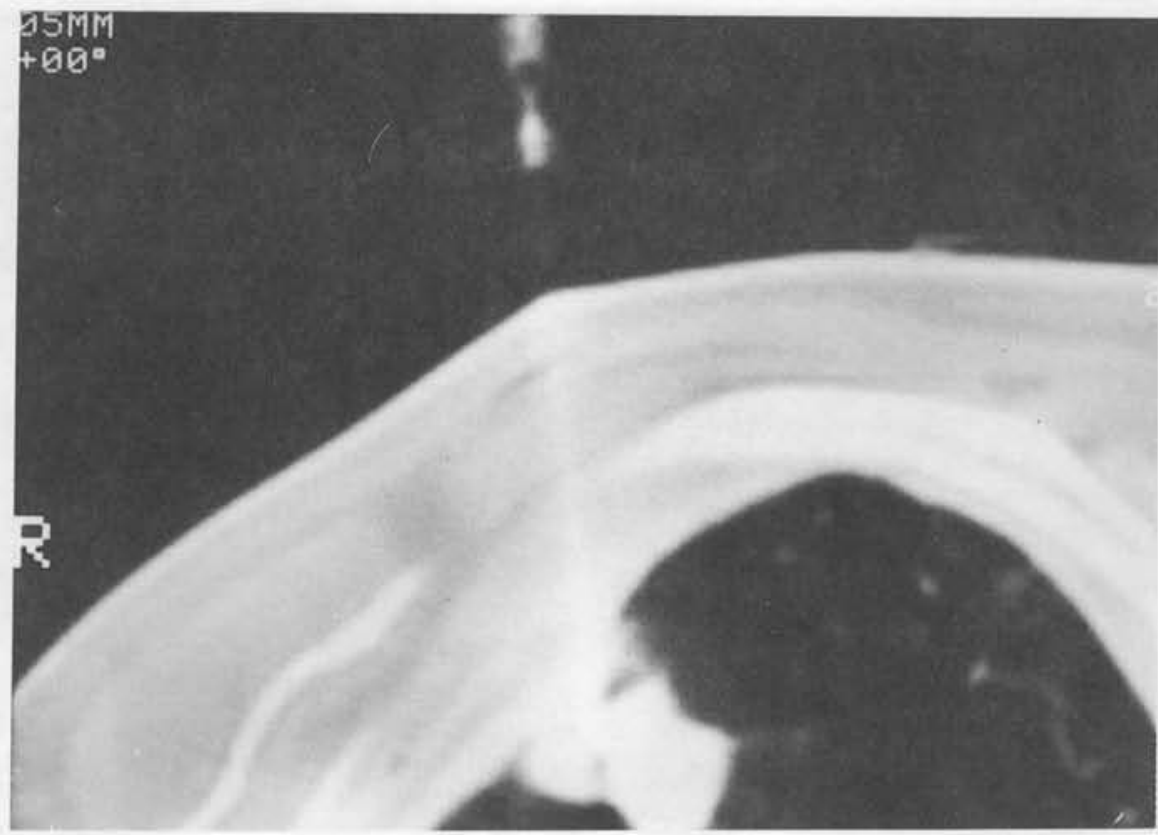

Figure 3 - Detail of Figure 2, showing the needle positioned inside the nodular lesion.

cases with an anatomoclinical diagnosis preceding or following the biopsy.

Sensitivity, specificity and predictive value depend on many factors in addition to the presence or absence of disease. ${ }^{8}$ The predictive value of a test depends on the prevalence of a given disease. ${ }^{8}$ In the present study, the negative predictive value, VP(-) was low. This is explained by the fact that the study was carried out at a cancer hospital that receives cases screened at general hospitals and private offices, with a high prevalence of this disease. Thus, there is a reduction in the number of true-negative results, a variable that directly affects the VP (-) values. The calculation of specificity was not impaired only because there were no false-positive results in this study. However, the high prevalence of cancer in this population (96.2), and the positive predictive value of 100 percent indicate that a patient with a positive result has a high probability (certainty) of really having cancer.

The results obtained in this study, using CT-guided FNAB, in anatomic parts of the body when the access is difficult, recommend the use of this procedure as an efficient and safe method for the diagnosis of malignancy.

\section{RESUMO}

$\mathrm{Na}$ avaliação terapêutica e prognóstica de neoplasias malignas torna-se essencial um diagnóstico morfológico preciso. Vários relatos têm enfatizado a importância da punção aspirativa guiada por tomografia computadorizada no diagnóstico de neoplasias irressecáveis e na investigaçăo de metástases. O presente trabalho estuda a acurácia diagnóstica, a sensibilidade, a especificidade e os valores preditivos positivo e negativo obtidos com esta técnica. De 1991 a 1994 , foram realizadas 210 punçōes aspirativas guiadas por tomografia computadorizada (TC) em 207 pacientes.

Foram $128(61,8 \%)$ pacientes do sexo masculino e $79(38,2 \%)$ do sexo feminino, com idade média de 41 anos (01 a 91 anos) As punçōes foram realizadas em diferentes localizaçōes, sendo pulmâo e fígado as mais frequèntes. Quanto aos diagnósticos. os casos foram assim distribuidos: 41 casos $(19,52 \%)$ com o diagnóstico de negativo para células neoplàsicas, 131 (62.38\%) de positivo, sendo que destes, em $54 \%$ foi possivel o diagnóstico da linhagem citológica. Em $14(6,67 \%)$ casos foi realizado o diagnóstico de suspeito (células atípicas) e em $24(11,43 \%$ ) casos o material foi considerado insuficiente. Dos 210 casos, 106 apresentavam exame anatomo-patológico e/ou seguimento clínico. Observou-se 47 casos $(44,3 \%)$ com diagnóstico prévio à punçāo e 50 casos $(56,7 \%)$ com exame histopatológico posterior. A comparação entre os diagnósticos citológicos e histopatológicos revelou indice de sensibilidade de $80,4 \%$, de especificidade de $100 \%$, valor preditivo positivo de $100 \%$, valor preditivo negativo de $16,7 \%$ e eficiência de $81,1 \%$. O presente estudo demonstra que a PAAF guiada pela tomografia computadorizada é uma técnica sensivel e altamente especifica para o diagnóstico de lesōes profundas. 


\section{REFERENCES}

1. Almeida Filho N, Rouquayrol, MZ. A definição de caso na epidemiologia. In Almeida Filho N, Rouquayrol MZ, eds. Introdução à epidemiologia moderna $1^{\mathrm{a}}$ ed. Rio de Janeiro: ApCE, 1990:27-47.

2. Böcking A, Klose, KC, Kyll, HJ, Hauptmann S. Cytologic versus histologic evaluation of needle biopsy of the lung, hilum and mediastinum. Sensitivity, specificity and typing accuracy. Acta Cytol 1995;39:463-71.

3. Ferrucci Jr JT, Witternberg J, Mueller PR, et al. Diagnosis of abdominal malignancy by radiologic fine-needle aspiration biopsy. A J R 1980;134:323-30.

4. Carson HJ, Martin GAS, Castelli MJ, Gattuso P. Unsatisfactory aspirates from fine-needle aspiration biopsies: A review. Diagn Cytopathol 1995;12:280-4.

5. Levine MS, Weiss JN Hariell, HJ Cameron TJ, Moser KM. Transthoracic needle aspiration biopsy following negative fiberoptic bronchoscopy in solitary pulmonary nodules. Chest 1988;93:1152-5.

6. Linsk JA, Franzen S. Introduction. In Linsk JA, Franzen S, eds. Clinical Aspiration Cytology 2nd ed. Philadelphia: J.B. Lippincott, 1989;1-15.
7. Lovett JV, Manalo PB, Barcia TC, Bomberger RA, Mc Grefor DB. Diagnosis of pulmonary masses by fine-needle aspiration. Am J Surg 1988;156:441-5.

8. Raab S. Diagnostic accuracy in cytopathology. Diagn Cytopathol 1994;10:68-75.

9. Reddy VB, Gattuso P, Abraham KP, Moncada R, Castelli MJ. Computed tomography-guided fine-needle aspiration biopsy of deep-seated lesions. A four-year experience. Acta Cytol 1991:35:753-6.

10. Sinner WN. Transthoracic needle biopsy of small peripheral malignant lung lesions. Invest Radiol 1973;8:305-14.

11. Stanley MW. False positive diagnoses in exfoliative cytology. Am J Clin Pathol 1995; 104:117-19 1995.

12. Stevens GM, Jacksman R J. Outpatient needle biopsy of the lung: Its safety and utility. Radiology 1984;151:301-4.

13. Suen KC. Diagnosis of primary hepatic neoplasms by fineneedle aspiration cytology. Diagn Cytopathol 1986;2:99-109.

14. Westcott JL. Direct percutaneous needle aspiration of localized pulmonary lesions: Results in 422 patients. Radiology 1980;137:31-5.

15. Westcott JL. Percutaneous needle aspiration of hilar and mediastinal masses. Radiology 1981;141:323-9.

16. Winning AJ, Mc Ivor J, Seed WA, Husain OA, Metaxas $\mathrm{N}$. Interpretation of negative results in fine-needle aspiration of discrete pulmonary lesions. Thorax 1986;41:875-9. 